\title{
Historical Gossip As Social Engineering To Build Historical Awareness
}

\author{
Asnawi ${ }^{1}$, Riyani $^{2}$, Bachtiar Akob ${ }^{3}$, Hanafiah ${ }^{4}$ \\ \{asnawi@unsam.ac.id\} \\ ${ }^{1}$ Universitas Samudra, Jl. Meurandeh, Langsa, Indonesia
}

\begin{abstract}
The main objective of social engineering trough historical gossip is to produce new knowledge, attitude and new historical awareness to Manyak Payed community of Aceh Tamiang Regency. This effort needs to be done to strengthen national integration. This technique is applied with historical gossip media on the local history object that intersects with the national history of Indonesia. The aforementioned Historical Object is the Expansion of Majapahit and a figure named Gajah Mada in Aceh Tamiang. The social engineering strategy is performed in two forms namely Normative-Reeducative and Persuasive Strategy which is presented as Acehnese art performances with programmed scenarios and focus group discussions. The target is the junior high school students in eight different schools in the Manyak Payed Subdistrict, Aceh Tamiang. Social engineering strategies utilize historical gossip of sites and myths related to the tomb which is claimed as the tomb of Gajah Mada in Kemasjidan Village, Manyak Payed Subdistrict, Aceh Tamiang. Using a combination of qualitative and quantitative methods, the results of the research show that there is an increase in historical awareness of the targeted community, with changes in knowledge, attitudes and historical perceptions. Such knowledge, attitudes and perceptions affect the ability of this society to think as historians have analyzed the past.
\end{abstract}

Keyword : Engineering, Historical, Build.

\section{Introduction}

Social engineering is the intervention or art of manipulating a scientific movement of a particular ideal vision aimed at influencing social change. Social change needs to be done because of the emergence of social problems as a result of the difference between das sollen (what should be done) with das sein (the reality). Social engineering can be interpreted as a collective action to solve social problems (collective action to solve social problems). Compared with social planning, social engineering has a broader or more pragmatic nature. Having a more definite meaning, while the object of management can be interpreted as a change in the broad sense, the object of social engineering is obvious, which is a social changes to a new order and system in accordance with what the engineer wants [1].

In addition to the aforementioned meanings, social engineering can also be interpreted as a process of planning, mapping and implementation in the context of changing the structure and culture of a social basis of society. Historically, there have been many theories about the causes of the occurrence of the social change, some arguing that society is changing for several things: First, Ideas; The way of life, the world view and the values. The main political 
events that have become historical records as a result of media manipulation and government propaganda as happened in Iraq [2].

Social engineering can also be utilized to overcome problems in various fields related to community life. Social engineering can also be used to change the life of democracy, rural institutions and the economy [3]. Its can be utilized also to change the condition of a society related to their historical understanding and awareness. Thus Social Engineering can function as a National Unifying Tool. Social engineering is a tool capable of integrating society. This becomes possible because social engineering is aimed at changing or controlling stagnation due to certain circumstances. In a historical perspective, the process of national integration through social engineering is done by mainstreaming the discourse that leads to the formation of national insight through the implantation of the ideology of nationalism and state slogan.

Social engineering in this research is not a kind of Historical bending, it is an attempt to change the knowledge, attitude, and perception of a society related to events and important figures of the Indonesian archipelago which has been understood in a lame way, hampering the maturity of society towards its national insight. The events and figures are Majapahit Expedition and a figure named Gajah Mada in East Aceh. The oral tradition growing within this community group leads to negative attitudes and perceptions that emerge as historical gossip and are not followed by the effort to build a historical awareness in the community.

The oral tradition that develops in Aceh is sometimes too subjective and gives rise to inequality in position. There is even a claim to the ancient tomb that is believed to be the grave of Patih Gajah Mada with various stories that are recounted from one generation to the next generation. This story essentially has a core with certain facts, usually, the core fact is quickly shrouded in the element of subjective belief or there is a confusion between facts with the beliefs, attitudes, values, and perceptions of a community group. The way of conveying this fact often resembles the delivery of a gossip (full of extra frills according to the speaker's mood). Jan Vasian labeled the above explanation with the term "historical gossip" which is a gossip with historical value.

Historical gossip can basically be used as a social Engineering medium, by constructing a historical gossip rival in an effort to build the historical awareness. Historical awareness is an attempt to change the cognition of society which can be conducted by inviting people to think the same way the historians analyze the past. Historical data presented are selected historical data, in order to achieve social engineering objectives. The issues that are going to be addressed through this research are (1). What is the technical implementation of social engineering by applying historical gossip?, (2) What is the condition of knowledge, attitudes and perceptions of the targeted community before and after social engineering?.

\section{Method}

The method used in this research is a combination of qualitative and quantitative methods. Qualitative research is an embedded research with an interactive analysis, while quantitative research used data collection technique in the form of questioner with a combination of Likert scale and Guttaman Scale to obtain valid data about knowledge, attitude and perception of target community on Pre and Post Engineering conditions. [4] Quantitative data are analyzed and interpreted in the form of quantitative and non-quantitative, as well as observation and interview data to deepen. This research was conducted in Manyak Payed sub-district by taking a potential target of Junior High students at 8 different schools, with the target of 400 people. 
The selection of these objectives is based on logical considerations, these students are in the age range where relatively easy to accept of new information, and quite potential to be an agent of renewal. Through the object of social engineering is expected that the knowledge, attitudes and perceptions of the social shift in the future. Overall data collection techniques used are: (a) structured and in-depth interviews (B) focus group discussions, (c) participation of observations and (d) Questioner.

\section{Result and discussion}

Specific targets to be achieved through social engineering is the realization of a society that has a good knowledge and awareness of history by showing an objective attitude toward the past and oriented to the future. At the same time giving the bargaining position to oral tradition in the effort of strengthening the local wisdom, both in local genius and local wisdom in the eastern part of Aceh especially in Manyak Payed Subdistrict Community.

In a case study of oral tradition related to the Majapahit Expansion in Eastern Aceh, the oral tradition can serve as a source of oral history, to complement the data void, detailing the event of Majapahit's expansion into the region. Critics that need to be deepened are focused on the emergence of the name of Gajah Mada as the leader of the expedition. The written source shows a contradiction with the growing oral tradition. The intellectuality of the object shows the triumph of the writing tradition equipped with some stronger data.

\subsection{Social Engineering Stages}

\subsubsection{Preparation}

The preparation of this Plan begins with regard to the recommendations generated in previous research. These recommendations include: urgent locations to be the focus of social engineering is Manyak Payed Sub-district (from Maja Pahit toponymy) in Aceh Tamiang District, with the findings that there is a growing oral tradition as to the grave of Gajah Mada, this is considered to have a signification of the final objectives to be Achieved.

\subsubsection{Set the purpose}

The specific purpose is the change of perception or knowledge and historical awareness of the targeted community regarding the events of Majapahit Expansion and Gajah Mada Figures. The second specific goal is the emergence of understanding and the ability of the targeted community to find local wisdom in the growing oral tradition related to the expansion of Majapahit and Gajah Mada figures in Aceh Tamiang Community, as with the study on how to do social engineering by dismantling public space in tribal communities in Iraq [5].

\subsubsection{Specify the target}

The targets of this social engineering include the community in the area of Manyak Payed, Aceh Tamiang by utilizing the younger generation as a catalyst or media liaison. The selected catalyst is students at the junior high at the region of Manyak Payed, consist of 5 public schools and 3 schools in equivalent level namely MTsN Manyak Payed, MTsS Ibdaul Islam and MTSS Sabilul Ulum. The selection is based on several considerations including: The educational environment is an effective environment for one of the social engineering strategies that are Normative-Reeducative Strategy. The nature of this modification strategy is indeed very slow and gradual but in the long run the results can be more significant. 


\subsubsection{Determining the strategy and social engineering configuration.}

The strategy used in social engineering consists of 2 (two) strategies integratively, both normative-reeducative strategy and persuasive strategy. The normative-reeducative strategy is carried out by reusing the oral tradition that became the wealth of the local community. Persuasive Strategy; Run through the formation of opinions and views of the community, using propaganda. The propaganda is conducted with a tool presented as Acehnese art performances as a medium to convey historical gossip. The manner or tactic used is to persuade, that is an attempt to change the behavior of the targeted community by identifying the social object on the trust or value of the agent of change. Based on various considerations, especially the effectiveness and efficiency of the impact, the social engineering will be done by utilizing the art of Aceh to be the medium of delivery of these social engineering missions.

\subsubsection{Submission of proposals to related parties}

Based on the targets set out in the planning, the second phase is implemented by: Coordination with related agencies especially the Education Department of Manyak Payed and the authority of all target schools.

\subsubsection{Implementation}

Implementation of strategies and forms of social engineering is carried out in accordance with the schedule agreed by the parties concerned. The speech art presented by artists in a road show from one school to another school. Art performances are conducted with scenarios or story content extracted from new data and a comparative historical gossip

\subsection{Knowledge, Attitudes and Perceptions of the Targeted Community Toward the Events of the History}

Social engineering is undertaken as described above aims to change the knowledge, attitudes, and perceptions of the targeted community who are considered less objective in assessing a particular historical event. The condition is caused by the characteristics of the people who tend to support oral culture and the lack of effort toward literacy culture. Knowledge in accordance with the cognitive level of Bloom [6] is at the level of C1 (knowledge) and C2 (Understanding). As for instilling attitudes and perceptions related to historical awareness focused on the level of C3 (Application) that is the development of historical data through heuristic and criticism activities and level C4 (analysis) (in the form of interpretation of historical data through comparison of several sources of history).

Historical gossip is related to all kinds of news and rumors are generated when events occur and are communicated through ordinary communication channels in a community and not lost when something new arrives. The main objective in social engineering is to build awareness of history by altering the knowledge, attitudes, and perceptions of the target community through historical gossip related to the expansion of Majapahit and Gajah Mada figures that intersect in the area of Manyak Payed, Aceh Tamiang. Changing the cognition of society is done by inviting people to think the same way as historians analyze the past. Historical data presented are selected historical data in order to achieve the social engineering objectives and purposes. Social engineering is also performed within its delivery strategy. As mentioned earlier the element of historical consciousness includes several things, including the sensitivity as to how the other time and place differ from our own time and place. Awareness or consciousness of basic sustainability in the events of the human history of all 
time. Ability to record and explain important changes. Sensitivity to diverse causes. The realization that all written history is an imperfect reconstruction in reflecting something or vice versa.

The phase of building a historical consciousness to change the cognition of society towards an object or event of history consists of several stages, namely: Inculcating history as fact, history as a series of causes, history as complexity and History as interpretation [7]. Based on these elements, a research questionnaire for measuring initial target knowledge is prepared as a closed question with a choice of multilevel answers. The following is the result of research on the condition of knowledge, attitudes and initial perception on social engineering targets:

Table 1. Historical knowledge of the social engineering target at pre-social engineering stage on the expansion of majapahit and gajah mada and a figure in manyak payed

\begin{tabular}{llcc}
\hline No & \multicolumn{1}{c}{ Aspects of research } & SUM & \% \\
\hline \multirow{4}{*}{$\begin{array}{l}\text { Do not know the existence of the Tomb that is claimed as the tomb of } \\
\text { Gajah Mada }\end{array}$} & 83 & 20,75 \\
Lack of information about the existence of the Tomb that is claimed as the & & \\
tomb of Gajah Mada & 223 & 55,75 \\
Know the existence of the Tomb that is claimed as the tomb of Gajah Mada & 94 & 23,5 \\
Very aware of such information & 0 & 0 \\
\hline 2 & Has no knowledge as to background of Gajah Mada Tombs existence & 129 & 32,25 \\
Lack of knowledge as to background of Gajah Mada Tombs existence & 213 & 53,25 \\
Have a good knowledge & 58 & 14,5 \\
Have an excellent knowledge & 0 & 0 \\
\hline $3 \quad$ Do not know the origin of the name Manyak Payed & 82 & 20,5 \\
Lack of knowledge about the origin of the name Manyak Payed & 219 & 54,75 \\
Know the origin of the name Manyak Payed & 99 & 24,75 \\
Very aware of the origin of the name Manyak Payed & 0 & 0 \\
\hline $4 \quad$ Having knowledge about the object of history, which sourced from friends & 88 & 22 \\
Having knowledge about the object of history, which sourced from the & 88 & 22 \\
parents & 83 & 20,75 \\
Having knowledge about the object of history, which sourced from & 62 & 15,5 \\
community leaders & & \\
Having knowledge about the object of history, which sourced from teacher & & \\
\hline
\end{tabular}

In point 1 it appears that from 400 respondents $23.5 \%$ have a good knowledge about the existence of Gajah Mada's Tomb in Desa Kemasjidan and only $20.75 \%$ who claimed have no idea about the existence of the tomb. However, the knowledge is not supported by a good understanding of the events of the existence of the tomb. Inquiries at questionnaire that leads to the aspect of understanding are illustrated in point no 2 . The range of respondents who have knowledge about the events of the existence of the tomb is around $14.5 \%$, and $53.25 \%$ of respondents have a lack of knowledge about the background of the event behind the existence of the ancient tomb.

The level of Knowledge regarding the toponymy meaning of 'manyak payed' in the chronology of Majapahit expansion in East Aceh, especially in Aceh Tamiang also quite low. Through point no. 3 it is known that only $24.75 \%$ of respondents who have a proper knowledge of the toponymy of their areas, and the rest of $54.75 \%$ have a lack of knowledge and $20.5 \%$ next did not have any knowledge at all. This can be understood as among the students in the area of Manyak Payed are not entirely from the same area. Nevertheless, the knowledge of regional toponymy has a better percentage compared to the knowledge of the existence of the tomb of Gajah Mada which is basically a historical gossip. 
It should be noted that respondents as social engineering targets only have the knowledge of history as fact and do not understand how history is actually a series of causes and consequences and as complexity. The objective of social engineering jumps on the historical ladder as an interpretation so that it is crippled and has no sufficient historical awareness. In particular the sensitivity to the causes of a multitude of events and the realization that all written history is an imperfect reconstruction in reflecting something. Or vice versa. This condition is possible because of $80 \%$ of respondents with a good and an excellent level of knowledge level gain such knowledge from information provided by friends (22\%) and from parents $(22 \%)$. Teachers as facilitators of the development of the historical awareness only accounted for $15.5 \%$ of the total respondents. New data and new interpretations of events are inserted in a speech art performance and processed through a focused discussions. The alteration of knowledge can be described as follows::

Table 2. Historical knowledge post-social engineering stage

\begin{tabular}{llcc}
\hline No & \multicolumn{1}{c}{ Aspects of research } & SUM & \% \\
\hline \multirow{2}{*}{$\begin{array}{l}\text { Do not know the existence of the Tomb that is claimed as the tomb of } \\
\text { Gajah Mada }\end{array}$} & 69 & 17,25 \\
Lack of information about the existence of the Tomb that is claimed as the & 176 & 44 \\
& tomb of Gajah Mada & 155 & 38,75 \\
& Know the existence of the Tomb that is claimed as the tomb of Gajah Mada & 0 & 0 \\
\hline & Very aware of such information & 72 & 18 \\
\hline 2 & Has no knowledge as to background of Gajah Mada Tombs existence & 177 & 44,25 \\
& Lack of knowledge as to background of Gajah Mada Tombs existence & 151 & 37,75 \\
& Have a good knowledge & 0 & 0 \\
& Have an excellent knowledge & 70 & 17,5 \\
\hline 3 & Do not know the origin of the name Manyak Payed & 188 & 47 \\
& Lack of knowledge about the origin of the name Manyak Payed & 142 & 35,5 \\
& Know the origin of the name Manyak Payed & 0 & 0 \\
& Very aware of the origin of the name Manyak Payed & 361 & 90,25 \\
\hline 4 & The new Knowledge and Understanding stems from the storyteller & & \\
\hline
\end{tabular}

Based on table 2 above it can see that the average activity category of students is already in the Good Based on the table it is known that a social engineering has changed the knowledge both at level $\mathrm{C} 1$ and $\mathrm{C} 2$. Historical knowledge of social engineering target respondents increased, we can see that respondents with a good knowledge amounted $38.75 \%$ and respondents with a poor knowledge by $44 \%$. The knowledge of the tomb of Gajah Mada based on a focused discussion develops on new knowledge and data, as there are two different opinions regarding the existence of this tomb. First, the information stating that the tomb is located somewhere in the oil palm plantation with a long shape cemetery form with old stone markers, while another opinion states that this tomb is located under the source of the spring watered by the village mosque Kemasjidan. This knowledge opens up useful new facts to deepen the awareness and understanding of targets regarding the element of historical consciousness, in which history can be judged as a complexity and history as an interpretation. The nature of doubt is the nature of historical inquiry and other fields of scholarship.

The level of understanding (C2) becomes more complex, with the range of respondents with good understanding amounted $37.75 \%$ and respondents with a poor understanding as of $44.25 \%$ from the total number of respondents as social engineering targets. The knowledge and understanding of toponymy Manyak Payed are also increasingly complex with new information gained through the art speech performance and directed discussion. 


\subsection{Historical attitudes and perceptions of social engineering target}

Attitude is an evaluative statement toward an object, person or event. It reflects one's feelings toward something. In the context of research, the historical attitude is an evaluative statement of historical objects, especially the beliefs on the origin and history of the tomb in Kemasjidan and Toponymy Manyak Payed as part of the historical chronology of Majapahit expansion into Aceh Tamiang. It is traced through item no. 4, 6, 7, 8 and 9 in the questionnaire given pre and post social engineering to know the attitude and the initial perception and condition of post social engineering.

Perception is the act of composing, recognizing and interpreting information to give a picture and understanding of something. The historical perception in this study refers to the main object of historical gossip issue, in order to obtain a holistic perception of comprehension, balanced between the interests of locality and national interest. The following will describe the results of the interpretation of data obtained through questionnaires and embedded with other data collection techniques as described earlier. Both tables will be presented in sequential order, to clarify the changes that occur.

Table 3. Historical attitudes and perceptions of social engineering target at pre-social ngineering stage on the expansion of majapahit and gajah mada in manyak payed

\begin{tabular}{|c|c|c|c|}
\hline No & Aspects of research & SUM & $\%$ \\
\hline \multirow{4}{*}{1} & Strongly believe that the Historical object is the tomb of Gajah Mada & 44 & 11 \\
\hline & Assured that the historical object is the tomb of Gajah Mada & 195 & 48,75 \\
\hline & Less sure the historical object is the tomb of Gajah Mada & 109 & 27,25 \\
\hline & Unsure that the historical object is the tomb of Gajah Mada & 11 & 2,75 \\
\hline \multirow[t]{4}{*}{2} & Very proud of its regional toponymy & 91 & 22,75 \\
\hline & Proud of its regional toponymy & 235 & 58,75 \\
\hline & Not really /less Proud of its regional toponymy & 61 & 17,75 \\
\hline & Not Proud of its regional toponymy & 3 & 0,75 \\
\hline \multirow[t]{4}{*}{3} & $\begin{array}{l}\text { The early nationalism that was endeavored through the expansion of } \\
\text { Majapahit was considered very successful }\end{array}$ & 67 & 16,75 \\
\hline & $\begin{array}{l}\text { The early nationalism that was endeavored through Majapahit expansion } \\
\text { was considered successful }\end{array}$ & 193 & 48,25 \\
\hline & $\begin{array}{l}\text { The early nationalism that was endeavored through the expansion of } \\
\text { Majapahit was considered less successful }\end{array}$ & 117 & 29,25 \\
\hline & $\begin{array}{l}\text { The early nationalism that was endeavored through Majapahit expansion } \\
\text { was considered unsuccessful }\end{array}$ & 41 & 5,75 \\
\hline \multirow[t]{4}{*}{4} & Unsure that Gajah Mada led the expansion of Majapahit to Aceh Tamiang & 80 & 20 \\
\hline & $\begin{array}{l}\text { Less sure /not really sure that Gajah Mada led the expansion of Majapahit } \\
\text { to Aceh Tamiang }\end{array}$ & 196 & 49 \\
\hline & Assured that Gajah Mada led the Majapahit expansion into Aceh Tamiang & 103 & 25,75 \\
\hline & $\begin{array}{l}\text { Strongly believe that that Gajah Mada led the expansion of Majapahit to } \\
\text { Aceh Tamiang }\end{array}$ & 21 & 5,25 \\
\hline \multirow[t]{4}{*}{5} & Unsure if other figures led the Majapahit expedition to Aceh Tamiang & 65 & 16,25 \\
\hline & Less sure other figures led the Majapahit expedition to Aceh Tamiang & 221 & 55,25 \\
\hline & Assured that other figures led the Majapahit expedition to Aceh Tamiang & 108 & 27 \\
\hline & $\begin{array}{l}\text { Strongly believe that other figures led the Majapahit expedition to Aceh } \\
\text { Tamiang }\end{array}$ & 6 & 1,5 \\
\hline
\end{tabular}


Table 4. Historical attitudes and perceptions of social engineering target at pre-social ngineering stage on the expansion of majapahit and gajah mada in manyak payed

\begin{tabular}{|c|c|c|c|}
\hline No & Aspects of research & SUM & $\%$ \\
\hline \multirow{4}{*}{1} & Strongly believe that the Historical object is the tomb of Gajah Mada & 44 & 11 \\
\hline & Assured that the historical object is the tomb of Gajah Mada & 178 & 44,5 \\
\hline & Less sure the historical object is the tomb of Gajah Mada & 130 & 32,5 \\
\hline & Unsure that the historical object is the tomb of Gajah Mada & 9 & 2,25 \\
\hline \multirow[t]{4}{*}{2} & Very proud of its regional toponymy & 95 & 23,75 \\
\hline & Proud of its regional toponymy & 238 & 59,5 \\
\hline & Not really /less Proud of its regional toponymy & 61 & 15,25 \\
\hline & Not Proud of its regional toponymy & 5 & 1,25 \\
\hline \multirow[t]{4}{*}{3} & $\begin{array}{l}\text { The early nationalism that was endeavored through the expansion of } \\
\text { Majapahit was considered very successful }\end{array}$ & 75 & 18,75 \\
\hline & $\begin{array}{l}\text { The early nationalism that was endeavored through Majapahit expansion } \\
\text { was considered successful }\end{array}$ & 215 & 53,75 \\
\hline & $\begin{array}{l}\text { The early nationalism that was endeavored through the expansion of } \\
\text { Majapahit was considered less successful }\end{array}$ & 90 & 22,5 \\
\hline & $\begin{array}{l}\text { The early nationalism that was endeavored through Majapahit expansion } \\
\text { was considered unsuccessful }\end{array}$ & 20 & 5 \\
\hline \multirow[t]{4}{*}{4} & Unsure that Gajah Mada led the expansion of Majapahit to Aceh Tamiang & 67 & 16,75 \\
\hline & $\begin{array}{l}\text { Less sure /not really sure that Gajah Mada led the expansion of Majapahit } \\
\text { to Aceh Tamiang }\end{array}$ & 229 & 57,25 \\
\hline & Assured that Gajah Mada led the Majapahit expansion into Aceh Tamiang & 91 & 22,75 \\
\hline & $\begin{array}{l}\text { Strongly believe that Gajah Mada led the expansion of Majapahit to Aceh } \\
\text { Tamiang }\end{array}$ & 13 & 3,25 \\
\hline \multirow[t]{4}{*}{5} & Unsure if other figures led the Majapahit expedition to Aceh Tamiang & 58 & 14,5 \\
\hline & Less sure other figures led the Majapahit expedition to Aceh Tamiang & 190 & 47,5 \\
\hline & Assured that other figures led the Majapahit expedition to Aceh Tamiang & 130 & 32,5 \\
\hline & $\begin{array}{l}\text { Strongly believe that other figures led the Majapahit expedition to Aceh } \\
\text { Tamiang }\end{array}$ & 22 & 5,5 \\
\hline
\end{tabular}

Based on the above table it appears that $11 \%$ of respondents strongly believe the tomb is the grave of Gajah Mada, $48 \%$ of respondents are just sure, $27.25 \%$ less sure and $2.75 \%$ stated unsure (question no.4). This is supported by the percentage data in question number 6 as to the possibility of Gajah Mada lead the expedition to Aceh by himself. Among the respondents who answered not possible at $20 \%$, Doubt $49 \%$, possibly $25.5 \%$, and very possibly $5.25 \%$. This belief changed after social engineering, with respondents answered not possible $16.75 \%$, $57 \%$ doubt, possibly $22.75 \%$, and very possibly $3.25 \%$.

The downward graph shows that the social engineering objectives have considered other possibilities according to aspects of historical consciousness. The aforementioned awareness is the sensitivity to how time and place differ from time and place of the historical object of gossip. The ability to record and explain important and meaningful changes and awareness that previously owned sources has not yet been perfect in reflecting something. Includes other possibilities of what has long been believed to occur in historical objects. The possibility is, among other things, there is a belief in another possibility that the leader of the Majapahit expedition to Aceh Tamiang is another figure, based on several interpretations on the historical sources presented in social engineering. $1.5 \%$ of respondents said it is possible and $27 \%$ said there might be another figure named Patih Sarwajala Nala who became the leader of the expedition this is supported by various historical sources available. This graphic increased 
post social engineering with a respondent who stated very possible amounted $5.5 \%$ and $32.5 \%$ stated possible.

At the pre-social engineering stage, the Perception of the target On the efforts of Gajah Mada in realizing the 'Sumpah Palapa' (the Palapa Oath) as a form of early Indonesian nationalism can be categorized as very low, stating that the effort is not or less successful. Respondents who stated less successful as much as $29.25 \%$ and stated unsuccessful as much as $5.75 \%$. However, after social engineering $18,75 \%$ stated very successful, and $53.75 \%$ stated the initial nationalism endeavors was successfully made with the process of migration and inter-island introductions.. This means that each locality and a particular ethnic community have their respective roles and are supportive of each other. This is supported by the knowledge of historical data explaining that there are community groups originating from Aceh Tamiang in Majapahit kingdom with a role that can be traced deeper. Thus, with this social engineering, we can explore the positive values of a historical event. As an indicator of success, social engineering target societies have been able to take on positive values As directed by storytellers through a ranking of understanding on target audiences, which are (1) There are many names of areas in Aceh Tamiang associated with the events of Majapahit expedition in Aceh Tamiang (2) The emergence of local genius and local wisdom associated with the event in the form of imagery and poem. (3) The strength and cooperation of the people of Aceh Tamiang in an effort to cope with external threats. (4) Patriotism value of Aceh Tamiang and Manyak Payed community with various battle incidents. (5) The role of aceh Tamiang community in the Javanese kingdom after an expedition that led to the return of Majapahit troops to Java Island.

As well as the understanding of the social engineering target audience as to other possibilities related to the Tombs in the village of Kemasjidan Manyak Payed, The following sequence is the possibility of the ranking: Commander or Soldier of Majapahit, Gajah Mada, Patih Nala and other figures who are not related to the incident of Majapahit expansion.

\section{Conclusion}

Historical gossip which is constructed using Acehnese art performances with programmed scenarios and focus group discussions controlled by the storyteller in the community of Manyak Payed somewhat successful. The result is a more complex knowledge alteration. Historical attitudes and perceptions are increasingly open. These three things are a prerequisite for the awakening of historical awareness, with indicators of elemental achievement include: (1) The sensitivity as to how the other time and place differ from our own time and place, (2) awareness of basic continuity in the events of human history of all time, (3). Ability to record and explain important or meaningful changes, (4). Sensitivity to diverse causes, (5) The realization that all written history is an imperfect reconstruction in reflecting something or vice versa.

\section{Acknowledgment}

The authors acknowledment the asistance Ministry of technology research and higher education Indonesia. 


\section{References}

[1] Jack J T C and Akujobi C T 2017 Social Change 35491

[2] T Hilde and Kellner D 1996 Media Culture 13198

[3] M Humphreys et al 2015 Mimeo 20156

[4] S Cronholm and Hjalmarsson A 2011 Electron. J. Bus. Res. Methods 987

[5] P Pyla 2013 Archit. Hist 16

[6] A Amer 2006 Electron. J. Res. Educ. Psychol 4215

[7] P Summerfield 2016 Miranda 1215 